\title{
Influence of immersion depth of ladle shroud in liquid steel on range of transition zone for one-strand tundish during continuous casting of steel
}

\author{
Wpływ głębokości zanurzenia \\ wylewu osłonowego w ciekłej stali \\ na zakres strefy przejściowej \\ dla jednowylewowej kadzi pośredniej \\ podczas ciągłego odlewania stali
}

\begin{abstract}
This article presents the results of a computer simulation of the flow of liquid steel through a onestrand tundish. In this paper, we examine four immersion depths of a ladle shroud in liquid steel. The simulation was performed for a sequence of slab castings. The effect of the calculations were residence time distribution curves (RTD), type (F). Based on the distribution curves, the range of the transition zone for the different variants of the immersion depth of a ladle shroud were estimated. Based on the results of numerical calculations, it was found that increasing the immersion depth of the ladle shroud in liquid steel influences the range of the transition zone. For numerical simulations of the flow of liquid steel, the Ansys-Fluent program was used.
\end{abstract}

Keywords: sequence casting, tundish, ladle shroud, numerical modeling, transition zone

\section{Streszczenie}

W artykule przedstawiono wyniki symulacji komputerowej przepływu ciekłej stali przez jednowylewową kadź pośrednią. W pracy rozpatrzono cztery głębokości zanurzenia wylewu osłonowego w ciekłej stali. Symulację wykonano dla sekwencji odlewania wlewków płaskich. Efektem obliczeń było uzyskanie krzywych czasu przebywania RTD (Residence Time Distributions) typu (F). Na podstawie rozkładu krzywych oszacowano zakres strefy przejściowej dla poszczególnych wariantów głębokości zanurzenia wylewu osłonowego. Na podstawie wyników

Michał Bartosiewicz M.Sc. Eng., Adam Cwudziński D.Sc. Ph.D. Eng.: Czestochowa University of Technology, Faculty of Engineering Production and Materials Technology, Department of Metals Extraction and Recirculation, Czestochowa, Poland; bartosiewicz.michal@wip.pcz.pl, cwudzinski.adam@wip.pcz.pl 
obliczeń numerycznych stwierdzono, że wzrost głębokości zanurzenia wylewu osłonowego w ciekłej stali wpływa na zakres strefy przejściowej. Do symulacji numerycznej przepływu ciekłej stali zastosowano program Ansys-Fluent.

Słowa kluczowe: odlewanie sekwencyjne, kadź pośrednia, wylew osłonowy, modelowanie numeryczne, strefa przejściowa

\section{Introduction}

The method of the continuous casting of steel is currently the leading method of casting steel slabs, blooms and billets. Implementation of new techniques in the continuous casting of steel is dictated by the increasing requirements for steel of utility characteristics. Furthermore, in the process of the continuous casting of steel, an important economic aspect is considered due to its higher efficiency as compared to traditional casting. An important parameter describing the work of a tundish is the device's velocity and the direction of flow of liquid steel in the working volume of the tundish. This aspect contains several important conditions that need to be fulfilled. The movement of the steel influences the distribution of both temperature and turbulence. The flow of liquid steel should be shaped to eliminate the possibility of absorption into steel tundish powder, particles, or droplets of non-metallic inclusions. All are potentially dangerous for the quality of the steel. A tundish is one of the basic metallurgical devices that contributes to improving the quality of steel $[1,2]$. The tundish allows to perform metallurgical treatments in the continuous casting of steel (e.g., removing non-metallic inclusions) and hydrodynamic treatments (e.g., controlling the flow of liquid steel) $[3,4]$. The optimal flow of steel in a tundish improves the qualitative factors and overall performance [4]. The devices for liquid steel flow control are divided into three groups. The first concerns the elements related to the regulation of the flow of steel from the tundish to the mold (e.g., stopper rods). The second group consists of devices located inside the tundish (e.g., dams or impact pads). The third group creates a ladle shroud that supplies steel to the tundish. For the ladle, this group is a new point of research and has enjoyed significant success because of the growing trend concerning to optimization of construction in the steel industry, which allows for increased efficiency and a reduction in maintenance costs for the whole process [5-8]. This paper presents the results of computer simulations showing the influence of ladle shroud immersion of depth in liquid steel on the range of transition zone during a continuous casting succession of heats with different chemical compositions.

\section{Characteristic of investigated object}

In this paper, the object of the study is a one-strand, wedge-type tundish characterized by a capacity of $30 \mathrm{Mg}$. The liquid steel flows into the tundish via a ceramic ladle shroud. The purpose of this study is examine the effect of the immersion depth of the ladle 
shroud in the liquid steel on the range of the transition zone during the continuous casting of steel. Four immersion depths in the liquid steel have been selected for the ladle shroud. The basic variant used for industrial processes is $0.1 \mathrm{~m}$, and the others are proposed variants: $0.2 \mathrm{~m}, 0.3 \mathrm{~m}$, and $0.4 \mathrm{~m}$. The considered tundish is equipped a dam that contains two overflow windows. Moreover, the tundish is equipped with a stopper rod system, whereby it is possible to control flowing steel from the tundish to the continuous casting mold. Detailed information about the examined object have been described in papers $[9,10]$. Figure 1 shows the model of tundish with the proposed variants of the immersion depth of the ladle shroud.

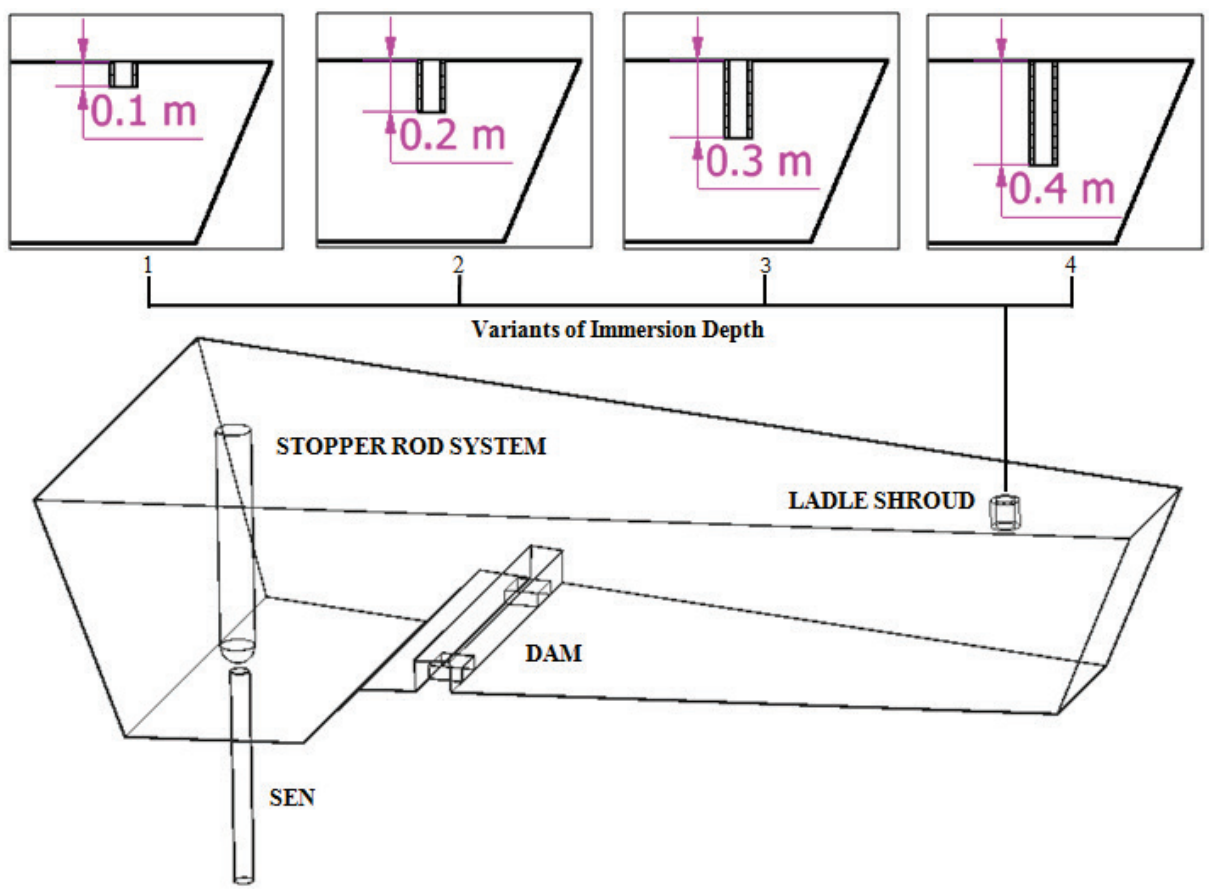

Fig. 1. Virtual model of tundish with examined variants of ladle shroud immersion depth

\section{Methodology of research}

Four models of tundish were made using the Gambit computer program, including four immersion depths of the ladle shrouds in liquid steel. In the area of calculation, each examined geometry created a mesh consisting of a number of control volumes $(170,000 \pm 5000$ elements). 
For a computer simulation of the flow of liquid steel, we used Ansys-Fluent software (which applies the method of numerical integration based on the control volumes of the virtual models) [11]. A mathematical model of the flow of liquid steel in the tundish consists of a differential equation of continuity, momentum, and energy. Taking into account the turbulent character of the flow of steel in the tundish, the $k-\varepsilon$ Realizable turbulence model was used in order to introduce the stochastic motion of the liquid steel. Detailed information about the mathematical model has been presented in papers $[12,13]$.

The calculations were performed under the conditions of the continuous casting of slabs characterized by dimensions $1.5 \times 0.225 \mathrm{~m}$, which were cast at a speed of $0.015 \mathrm{~m} / \mathrm{s}$. In each of the examined variants, the liquid steel at a temperature of $1823 \mathrm{~K}$ was flown into the tundish through the ladle shroud at a speed of $1.316 \mathrm{~m} / \mathrm{s}$. The upper surface of the examined objects imitated the contact point of air with liquid steel (wall function with zero tangential stress). The kinetic energy of turbulence was accepted at a level of $0.0173 \mathrm{~m}^{2} / \mathrm{s}^{2}$, whereas the dissipation of the kinetic energy of turbulence was defined as $0.065137 \mathrm{~m}^{2} / \mathrm{s}^{3}$. Thermal conditions, including heat fluxes on the respective surfaces of the tundish were accurately described in paper [9].The physical properties of the liquid steel were applied in the calculation, such as the density described by Equation (1) and viscosity of $0.007 \mathrm{~kg} / \mathrm{m} \cdot \mathrm{s}$, specific heat of $750 \mathrm{~J} / \mathrm{kg} \cdot \mathrm{K}$, and thermal conductivity of $41 \mathrm{~W} / \mathrm{m} \cdot \mathrm{K}$ :

$$
\rho=8300-0.7105 T
$$

where:

$$
\begin{aligned}
& \rho \text { - density }\left[\mathrm{kg} / \mathrm{m}^{3}\right], \\
& T \text { - temperature }[\mathrm{K}] .
\end{aligned}
$$

In the paper, curves of time residence RTD type (F) for the four different immersion depths of the ladle shroud were appointed. $F$ curves are a graphical interpretation of concentration changes of the chemical compositions of the casting heats. In paper [14], the authors recognized the range of the transition zone as between 0.2 and 0.8 dimensionless concentration. The sequential casting of different steel grades requires, as small as possible range of the transition zone. Taking into account the economic aspects of the industrial conditions, it is beneficial that the amount of casted steel that doesn't fulfill the standards of chemical compositions were similar to the smallest. In paper [14], it was indicated that the transition zone should adopt values from 0.1 to 0.9 of dimensionless concentration during slab casting. In addition, taking into account the species of the casting steel, the range of the transition zone can be modified to interval $0.1-0.6$ or 0.4-0.6 dimensionless concentration, for example (which is described in paper [15]). For the researches in this article, the range of the transition zone during the sequence casting of steel is defined within a range of 0.2 to 0.8 dimensionless concentration on SEN, which has been successfully verified in the industry [16]. 


\section{Computation results}

Numerical simulation of the flow of liquid steel through the tundish for four variants of the immersion depth of the ladle shroud were performed. Identical values of the initial conditions for all variants of the simulations were assumed in all of the investigated variants of immersion of the ladle shroud in liquid steel. The obtained RTD-type (F) curves were essential for describing the range of the transition zone during the continuous casting of steel, taking into account the casting succession of different grades of steel or during the application of the sequential casting technology. Figure 2 presents the four type- $F$ curves corresponding to the four variants of immersion depth of the ladle shroud in liquid steel. It was assumed that the range of the transition zone was comprised of an interval between 0.2 and 0.8 dimensionless concentration. Analyzing the position of the $\mathrm{F}$ curves, it was determined that the immersion depth of ladle shroud in liquid steel influences the range of the transition zone.

a)

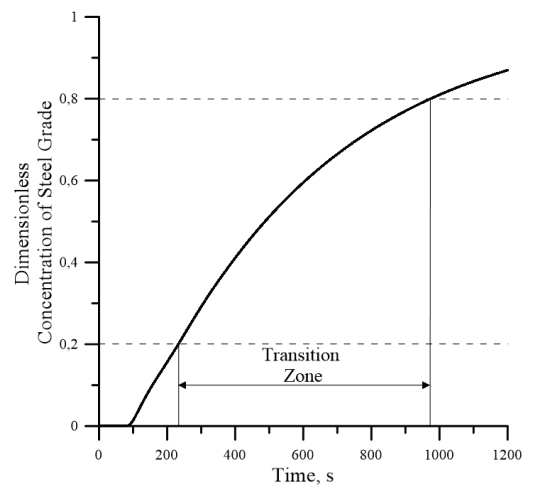

c)

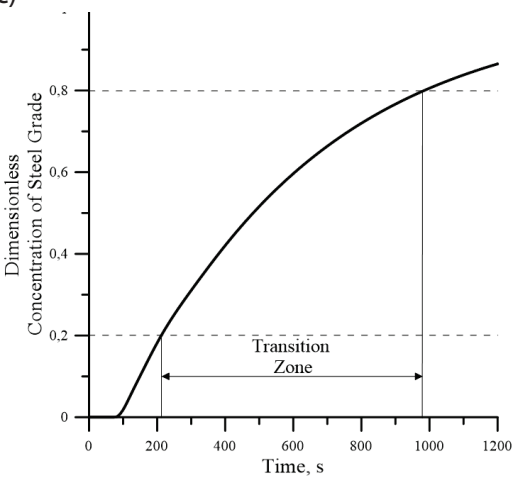

b)

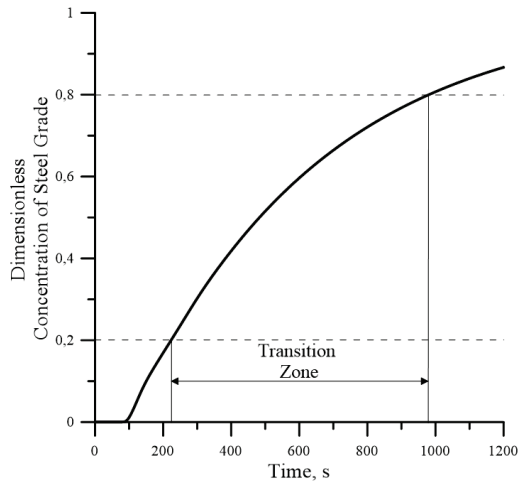

d)

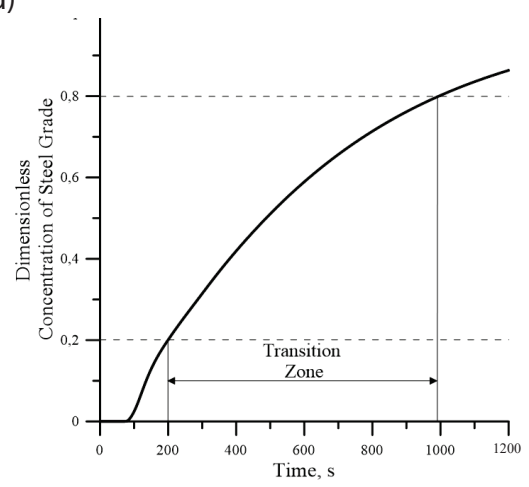

Fig. 2. RTD type (F) curves for respective variants of immersion depth of ladle shroud in liquid steel: a) $0.1 \mathrm{~m}$;b) $0.2 \mathrm{~m}$; c) $0.3 \mathrm{~m}$; d) $0.4 \mathrm{~m}$ 
Particularly, visible changes in the transition zone can be seen by comparing the $\mathrm{F}$ curves of the variants with the immersion of the ladle shroud in liquid steel to depths of $0.1 \mathrm{~m}$ and $0.4 \mathrm{~m}$. This indicates that the variant of the ladle shroud immersed in the liquid steel to a depth of $0.1 \mathrm{~m}$ is optimum due to the lowest range of the transition zone. The result of the computer simulation for the variant with the ladle shroud of an immersion depth of $0.1 \mathrm{~m}$ in liquid steel are shown in paper [17]. Table 1 presents the results of the formation of a transition zone in regard to all examined variants. Reading the data from Table 1, it should state that the increase of the immersion depth of the ladle shroud in liquid steel increases the range of the transition zone. A linear increase of the transition zone was obtained in relation to the immersion depth of the ladle shroud in liquid steel in the examined tundish. An amount of casted transition steel using the ladle shroud characterized by an immersion depth of $0.1 \mathrm{~m}$ is formed at a level of $26.3 \mathrm{Mg}$ and a length of $11.12 \mathrm{~m}$ for the slabs. The mass of the casted steel in the transition zone for the tundish with the immersion of the ladle shroud at depths of $0.2 \mathrm{~m}$ and $0.3 \mathrm{~m}$ are 26.9 and $27.4 \mathrm{Mg}$, respectively. The longest range of the transition zone were obtained for the tundish with an immersion depth of the ladle shroud at $0.4 \mathrm{~m}$. Then, the mass of the casted steel is $28.2 \mathrm{Mg}$.

Table 1. Transition zone for examined variants of immersion of ladle shroud

\begin{tabular}{|c|c|c|c|}
\hline $\begin{array}{c}\text { The immersion } \\
\text { depth ladle shroud } \\
\text { in liquid steel } \\
\text { [m] }\end{array}$ & $\begin{array}{c}\text { The time } \\
\text { of transition zone } \\
{[\mathbf{s}]}\end{array}$ & $\begin{array}{c}\text { The length } \\
\text { of slab } \\
\text { [m] }\end{array}$ & $\begin{array}{c}\text { The mass of slab } \\
\text { [Mg] }\end{array}$ \\
\hline 0.1 & 741.4 & 11.12 & 26.3 \\
\hline 0.2 & 756.9 & 11.36 & 26.9 \\
\hline 0.3 & 772.2 & 11.58 & 27.4 \\
\hline 0.4 & 795.6 & 11.93 & 28.2 \\
\hline
\end{tabular}

\section{Summary}

Controlling the flow of liquid steel in a tundish is an important aspect of the quality of cast steel. One of helpful parameters describing the hydrodynamic phenomena in the tundish is the RTD-type (F) curve, which allows for the rate of range in the transition zone. In summary, the simulations made it possible to phrase the following conclusions:

- The change of the immersion depth of a ladle shroud in a one-strand wedge-type tundish influences the range of the transition zone. 
- In the present variant, the length of the transition zone successively increases with an increase in the immersion depth of a ladle shroud in liquid steel. By increasing the immersion of a ladle shroud by $0.3 \mathrm{~m}$ as compared to the basic variant, the amount of steel with a transition chemical composition increases by $1.9 \mathrm{Mg}$.

\section{Acknowledgements}

This research was supported in part by PLGrid Infrastructure.

\section{References}

[1] Thomas B.G.: Modeling of Continuous Casting Defects Related to Mold Fluid Flow. AIST Transactions, 3, 5 (2006), 2-17

[2] Chattopadhyay K., Isac M., Guthrie R.I.L.: Physical and Mathematical Modelling to Study the Effect of Ladle Shroud Mis-Alignment on Liquid Metal Quality in a Tundish. ISIJ International, 51 , 5 (2011), 759-768

[3] Wang G., Yun M., Zhang C., Xiao G.: Flow Mechanism of Molten Steel in a Single-Strand Slab Caster Tundish Based on the Residence Time Distribution Curve and Data. ISIJ International, 55, 5 (2015), 984-992

[4] Sahai Y., Emi T.: Criteria for Water Modeling of Melt Flow and Inclusion Removal in Continuous Casting Tundishes. ISIJ International, 36, 9 (1996), 1166-1173

[5] Zhang J., Yang S., Li J., Yang W., Wang Y., Guo X.: Large Eddy Simulation on Flow Structure in Dissipative Ladle Shroud and a Tundish. ISIJ International, 55, 8 (2015), 1684-1692

[6] Solorio-Diaz G., Davila-Morales R., Barreto-Sandoval J. de J., Vergara-Hernández H.J., Ramos-Banderas A., Galvan S.R.: Numerical Modelling of Dissipation Phenomena in a New Ladle Shroud for Fluidynamic Control and Its Effect on Inclusions Removal in a Slab Tundish. Steel Research International, 85, 5 (2013), 863-874

[7] Zhang J., Li J., Yan Y., Chen Z., Yang S., Zhao J., Jiang Z.: A Comparative Study of Fluid Flow and Mass Transfer in a Trumpet-Shaped Ladle Shroud Using Large Eddy Simulation. Metallurgical and Materials Transactions B: Process Metallurgy and Materials Processing Science, 47, 1 (2016), 495-507

[8] Davila-Morales R., Garcia-Hernández S., Barreto J. de J., Ceballos-Huerta A., Calderon-Ramos I., Gutierrez E.: Multiphase Flow Modeling of Slag Entrainment During Ladle Change-Over Operation. Metallurgical and Materials Transactions B: Process Metallurgy and Materials Processing Science, 47, 4 (2016), 2595-2606

[9] Cwudziński A., Jowsa J.: Numerical Simulation Heat Transfer in the Slab Tundish. Metallurgy and Foundry Engineering, 33, 2 (2007), 97-103

[10] Cwudziński A.: Numerical Simulation of Liquid Steel Flow in Wedge-type One-Strand Slab Tundish with a Subflux Turbulence Controller and an Argon Injection System. Steel Research International, 81, 2 (2010), 123-131

[11] Jha P.K., Rao P.S., Dewan A.: Effect of Height and Position of Dams on Inclusion Removal in a Six Strand Tundish. ISIJ International, 48, 2 (2008), 154-160

[12] Cwudziński A.: Numerical and Physical Prediction of Hydrodynamic Conditions in One-Strand Slab Tundish. Metallurgical Research \& Technology, 111, 1 (2014), 45-55

[13] Cwudziński A.: Numerical and Physical Modeling of Liquid Steel Active Flow in Tundish with Subflux Turbulence Controller and Dam. Steel Research International, 85, 5 (2014), 902-917

[14] Chakraborty S., Hirose T., Jones B., Dukelow D.A.: Transition Reduction and Simultaneous Maintenance of Steel Quality in Granite City Tundishes. Continuous Casting, 10 (2003), 41-46 
[15] Thomas B.G.: Modeling Study of Intermixing in Tundish and Strand during a Continuous Casting Grade Transition. Continuous Casting, 10 (2003),115-127

[16] Cwudziński A.: Regulation of Liquid Steel in the Continuous Casting Slab Tundish. PhD dissertation, Czestochowa University of Technology, Faculty of Materials Processing Technology and Applied Physics, 2008

[17] Cwudziński A.: Physical and Mathematical Simulation of Liquid Steel Mixing Zone in One Strand Continuous Casting Tundish. International Journal of Cast Metals Research, 30, 1 (2017), 50-60 